\title{
DESIGNING A JAVANESE SCRIPT LEARNING MOBILE APPLICATION USING A PROTOTYPE MODEL
}

\author{
Endang Sri Palupi \\ Sistem Informasi \\ Universitas Bina Sarana Informatika \\ endang.epl@bsi.ac.id
}

\begin{abstract}
Abstrak
Aksara jawa adalah salah satu aksara khusus yang perlu dipelajari secara khusus. Pada tingkat sekolah dasar sampai tingkat menengah atas di propinsi Jawa tengah terdapat mata pelajaran bahasa daerah yaitu bahasa jawa yang ada aksara jawa. Aksara jawa berbeda dengan tulisan latin yang digunakan sehari - hari, sehingga butuh pemahaman dan pengajaran khusus. Masih banyak murid yang mengalami kesulitan belajar aksara jawa serta terbatasnya waktu belajar di sekolah dasar untuk mata pelajaran bahasa jawa. Selain untuk membantu para murid agar lebih mudah belajar aksara jawa, aplikasi ini dirancang agar masyarakat luar juga bisa belajar aksara jawa untuk melestarikan budaya dan lebih mencintai budaya yang ada di Indonesia. Model yang digunakan pada pembangunan aplikasi mobile tersebut adalah model prototype dengan metode ini penulis dapat berinteraksi langsung dengan user sehingga dapat memberitahukan kesulitannya, memberikan masukan apa saja yang dapat ditetapkan pada aplikasi, dan apa saja yang dibutuhkan user. Aplikasi ini bisa bermanfaat untuk mempelajari aksara jawa dengan memanfaatkan teknologi informasi sesuai perkembangan jaman.
\end{abstract}

\section{Kata Kunci: Aksara Jawa, Budaya, Teknologi Informasi}

\begin{abstract}
Javanese script is one of the special characters that need to be studied specifically. At the elementary to high school level in central Java province, there are regional language subjects, namely Javanese language that has Javanese script. Javanese characters are different from the Latin writings used daily, so it requires special understanding and teaching. There are still many students who have difficulty learning Javanese script and limited learning time in elementary school for Javanese language subjects. In addition to helping students to learn Javanese characters more easily, this application is designed so that outsiders can also learn Javanese characters to preserve the culture and love the culture in Indonesia more. The method used in the development of mobile applications is the prototype model with this model the author can interact directly with the user so that it can tell the difficulty, provide inputs on what can be set on the application, and what is needed by the user. This application can be useful to learn Javanese characters by utilizing information technology according to the development of the times.
\end{abstract}

Keywords: Javanese Script, Culture, Information Technology

\section{INTRODUCTION}

In all provinces in Indonesia, there are subjects in their respective regional languages. One of them is the Javanese language subject which uses the Javanese script. Many students have difficulty in this lesson and need time and a sufficiently detailed understanding of this Javanese script, while the time for learning Javanese subjects at school is very limited. (Permana \& Nourmavita, 2017) The difficulty factor in learning Javanese script is because Javanese characters are different from the commonly used alphabets, having their own rules in each script. The influence of the globalization era also makes children generally reluctant to learn in more detail Javanese characters. The fact is that students' interest in learning Javanese script has not been fully developed and they consider Javanese script a difficult subject, especially the chapter on writing Javanese characters and they don't like it. (Saputri, 2016) So it needs innovations to attract interest in learning while preserving culture and customs using information technology according to the times. This application can be accessed via smartphones based on Android and iOS.

Previous research entitled Learning Javanese Script for Elementary School Students 
Using Board Game Media which can be accessed on a smartphone. The result of this research is that Board Games are more effective as a learning medium at the elementary level. This Board Game application is a web application so you have to use a browser and require an internet connection. In this study the author uses a mobile application, its use can be offline based so that it does not require an internet connection, although certain parts require an internet connection, for example in the login menu. (Avianto \& Prasida, 2018)

Then in another study entitled Interactive Applications of Javanese Script Learning, this study made Javanese script applications with application design methods using Macromedia Flash CS3 which was carried out in 2 stages, namely: determining the learning activity scenario and making program menu design. (Widihastuti \& Khosyi, 2012) This application uses an offline desktop application so that it does not require an internet network, requires a data memory of 14.6 $\mathrm{MB}$ so that it can be stored in data storage devices with even small capacities. This study uses a desktop application, while the authors in this study use a more concise mobile application. (Widihastuti \& Khosyi, 2012)

Then in another study entitled Interactive Applications of Javanese Script Learning, this study made Javanese script applications with application design methods using Macromedia Flash CS3 which was carried out in 2 stages, namely: determining the learning activity scenario and making program menu design. (Widihastuti \& Khosyi, 2012) This application uses an offline desktop application so that it does not require an internet network, requires a data memory of 14.6 MB so that it can be stored in data storage devices with even small capacities. This study uses a desktop application, while the authors in this study use a more concise mobile application (Widihastuti \& Khosyi, 2012)

The next journal entitled Digitalization of Javanese Script and Utilization as Learning Media for Teacher Deliberations for Javanese Subjects at SMP Klaten Regency. One of the learning media in this research is by installing Javanese characters on the computer so that we can type Javanese characters using the keyboard just like normal typing. for example to bring up the ha character using the key; na $\sim$ n; ca $\sim$ c; ra $\sim$ r; ka $\sim$ k; and so on, including couples (Aribowo, 2018) in this study must use a computer or desktop, while this research is sufficient to use a more practical smartphone, can be done anytime and anywhere. (Aribowo, 2018)
In the Komtika journal, entitled Androidbased Let's Learn Arabic Application Design for Early Childhood, a study was conducted to make Arabic applications for early childhood. The system created displays Arabic material and questions in a multiple-choice format. The application is made with images that are full color and easy to digest for early childhood. In contrast to this research, the material apart from writing is also in the form of sound, correct pronunciation, and the questions given are not multiple choice but an essay (Rosadi, Widyanto, \& Sunarni, 2018).

In the journal entitled Application Design of an Android-based Javanese-Indonesian Dictionary, Risa Wati and Siti Ernawati designed the waterfall model and used Eclipse software, the application can only be used on Android. This application is in the form of a dictionary, which provides information on the meaning of Javanese vocabulary in Indonesian. Unlike this journal, the application that the author designed provides information about Javanese characters, pair rules, and pronunciation. Applications can also be used on android and iOS.(Wati \& Ernawati, 2018)

A similar journal entitled Designing Mobile Application Design for Recognition of Javanese Letters (Javanese Script) based on Android was made by Ega Feri Romawati and colleagues. This journal designs a mobile application on the Javanese script on Android using the waterfall method. The difference with this journal is that the menu in the application does not have a list of rules, while the application that the author designed has a list of Javanese script rules, for example, a list of rules:

1. Wulu rules for changing letters to vowel "i" and examples of their use in Javanese script.

2. The syllable rules for changing a letter into a vowel "u" and examples of their use in Javanese script. (Feri Ega, Widaningrum i, 2020)

Another journal entitled Android-Based English Learning Application Design was written by Sitti Aisa and Asmah Akhriana in 2019. This journal designed an Android-based English learning application with menus of information about the present, past, future, past future, and there is a speaking menu. which can display sound. The difference with the journal that the author makes is that the journal is only based on android. (Aisa \& Akhriana, 2019)

In another journal entitled Introduction to Javanese Script Words Using the K-Nearest Neighbor Algorithm made by Zaky Mukhoyyar in 2015 , provides information on translating Javanese characters into alphabets using digital image 
processing and the K-Nearest Neighbor algorithm method. The difference with this journal is that the application contains a complete menu of all characters, both in Javanese and in the alphabet, then it is equipped with pairing rules and pronunciation rules so that users can learn to compose Javanese characters by themselves.

This research was designed with a Prototype Model to understand the desired system specifications and speed up the application development process by making a prototype first. (Putra, Eldiana, \& Aryani, 2020) Prototyping produces an early working version that is built quickly from the proposed information system, which is called a prototype. Prototyping, which involves repeating a sequence of analysis, design, modeling, and testing, is a common technique that can be used to design anything from a new home to a computer network. (Tilley \& Rosenblatt, 2017) The purpose of this study is to preserve the culture and help students learn Javanese characters more easily and attractively via smartphones offline without having to use quotas.

\section{RESEARCH METHODS}

In this design model, the writer uses a prototype model to directly interact with the user. Users can tell their difficulties and provide input on what can be determined in this application feature (Wardhani \& Wijaya, 2020).

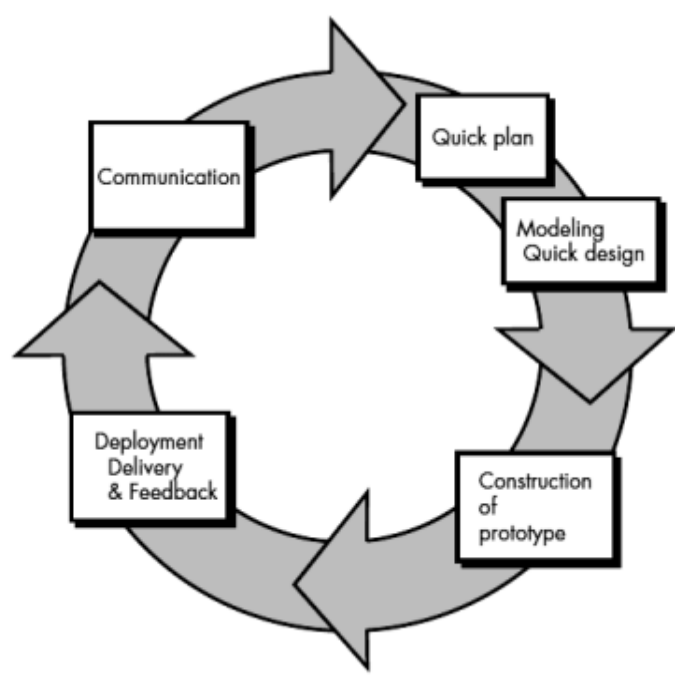

Source: (Pressman, Roger S, 2012)

Figure 1. Prototype Model

1. Communication

At this stage, the general flow of the system will be explained. Communication carried out is to discuss the business process system to be developed. The communication process is carried out by interviewing to listen and find out the user's needs for the product.

\section{Quick Plan}

Planning is fast and represents all known aspects of the software, and this planning forms the basis of prototyping. At the planning stage, it is quickly represented in the form of a flowchart.

3. Modeling Quick Design

Rapid design modeling focuses on representing the aspects of the software that the user can see, such as input and output. At this stage, a fast and accurate application interface is designed. Rapid design modeling is depicted in a use-case diagram.

4. Construction Of Prototype

Making a prototype is done by applying the results of the system design into PHP programming which is supported by the bootstrap framework. So that the procedures that have been made can be understood by the machine and produce the expected expenses.

5. Deployment, Delivery, And Feedback

At this stage, an evaluation is carried out to look for the weaknesses and deficiencies of the system. The entire system will be tested with various possibilities to make sure the system is functioning properly. Then the user provides feedback which will be used to improve the system requirements specifications. Iteration occurs when the developer makes improvements to the prototype. (Manuhutu \& Wattimena, 2019)

\section{Flowchart System}

According to Jogiyanto (2005), a system flowchart is a flowchart that is similar to a system flowchart, which is to describe the procedures in the system. This chart explains the sequence of procedures that exist in the system. The system flow chart shows what is being done in the system. Making a flowchart system has rules and regulations that must be followed (Jogiyanto, 2005).

A flowchart is a graphic depiction of the steps and sequence of procedures of a program (Mesran, 2019). Flowcharts help analysts and programmers to solve problems into smaller segments and help in analyzing other alternatives in operation. Flowcharts usually make it easier to solve a problem, especially problems that need to be studied and evaluated further (Mesran, 2019) 


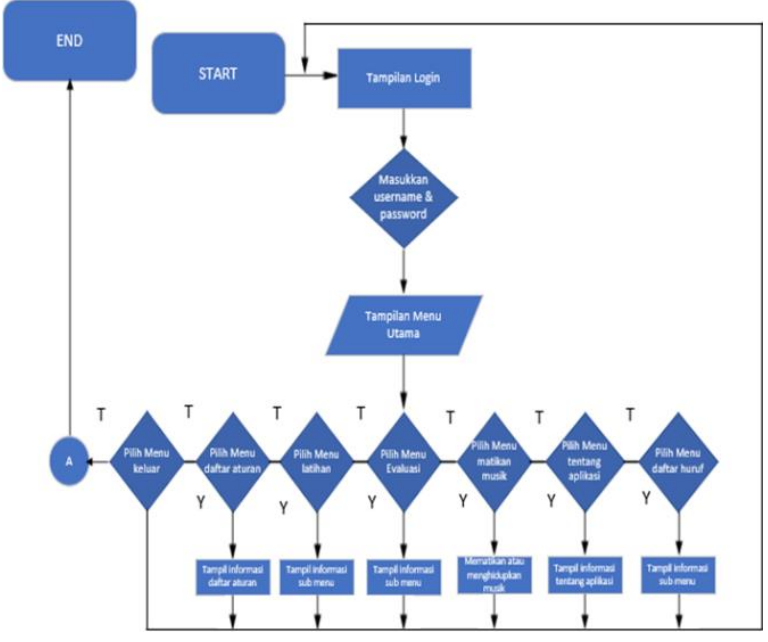

Figure 2. Application Flowchart

\section{Use Case Diagram}

Use case diagrams are one type of UML that describes the interaction between systems and actors, use case diagrams can also describe the types of interactions between users and the system. Use cases describe the external view of the system that we will model. (Widodo \& Prabowo, 2011) The use case model can be described in a use case diagram, but keep in mind, diagrams are not indicative of the model because the model is wider than the diagram. Use cases must be able to describe the sequence of actors who produce measurable values. (Suendri, 2019) Following the use case diagram designed in this study, use cases describe how user processes use this Javanese script learning application.

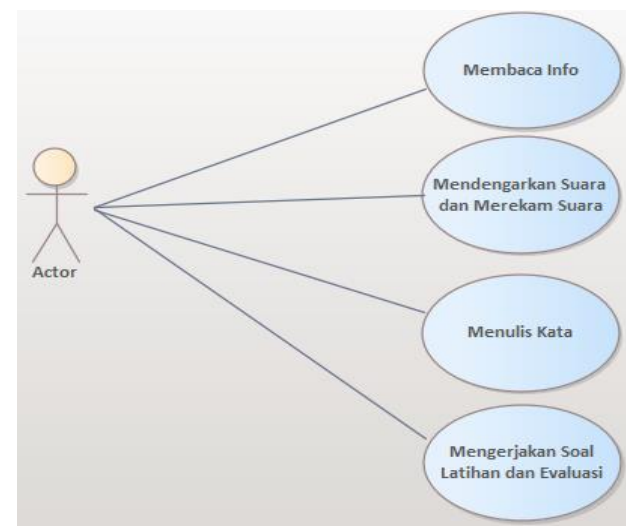

Figure 3. Use Case Diagram Design

\section{Low Fidelity Design}

It is a design with a low level of precision, it can be seen from the color, layout, typography, elements, and so on. This design can be done manually on paper or with the author's software using Figma.

\section{High Fidelity Design}

Is a design with a high level of precision, already has colors, layout, detailed typography resembling applications. This design uses the software. (Wardhani \& Wijaya, 2020)

\section{Types of research}

This type of research uses a qualitative approach with case studies at SDN Bayeman elementary school, Boyolali, Central Java. By looking at the background of the teaching and learning process in elementary schools, many students have difficulty learning Javanese script, and the learning time at school is not too long so they cannot explain in more detail.

\section{Time and Place of Research}

This research was conducted in December 2018, during Javanese class hours. The research location is SDN Bayeman, Bayeman Boyolali hamlet, Central Java Province.

\section{Research Target / Subject}

The target or research subject is elementary school students and teachers of SDN Bayeman Boyolagi in Central Java province who study Javanese script. To get the subject, the writer went to the elementary school where the author used to go to school and then made observations, interviews, and research.

\section{Research procedure}

This framework represents the steps and procedures that will be carried out in this research process. The research framework can be described in the following figure

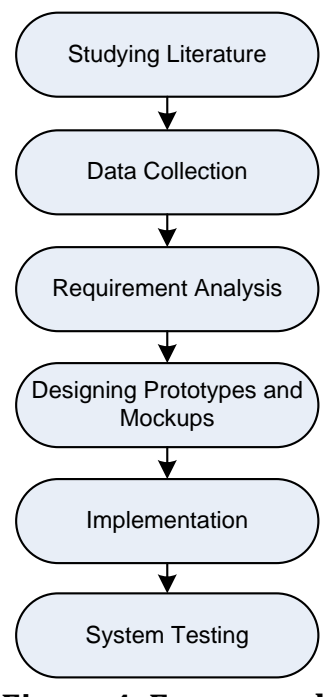

Figure 4. Framework 
1. Studying Literature

Studying and selecting literature that will be used as reference material, namely in the form of scientific journals, textbooks, websites, and articles related to Javanese language and Javanese script.

\section{Data Collection}

Collecting data other than direct interviews with respondents, direct interaction with users, as well as observations. Then the data is also taken from the literature in the form of scientific journals, articles, books, and websites.

3. Analyze Needs

Next is to analyze the needs, in this case, the writer conducts an assessment with the Javanese language teacher to explore in detail the needs needed by users in designing this Javanese script mobile application.

4. Designing the Prototype

Designing Low Fidelity Wireframe Prototype and High fidelity User Interface for Mobile Applications using Figma software.

5. Implementation

Implementation using the results of the execution of applications designed using mobile devices operating on mobile devices based on Android and iOS.

6. Evaluation

Evaluation or testing to determine the proper test of the application system that has been built is as expected and by testing can find out the weaknesses and strengths of the system designed so that improvements can be made at a later stage.

Data, Instruments, and Data Collection Techniques

Data collection techniques in this study are:

1. Literature study

Collecting literature, data, good information from scientific journals, books, websites, and magazines concerning info about Javanese script.

2. Observation

Read and observe directly Javanese script textbooks, and several times take Javanese language classes to observe how the learning process is.

3. Interview

Interview with student and teacher correspondents about how to learn the Javanese language, what obstacles are often faced, as well as confirm the results of the data obtained from observations. (RYFA, 2020)

\section{Data Analysis Technique}

This study, using qualitative data analysis techniques, namely analyzing elementary school students learning Javanese characters and finding out what is needed by the user. Data analysis is the process of systematically finding and compiling data obtained from interviews, field notes, and documentation, by organizing data into categories, describing them into units, synthesizing, arranging into patterns, choosing which ones are important and which ones will be studied, and make conclusions so that they are easily understood by oneself and others (Sugiyono, 2017). In general, students have difficulty learning Javanese characters, so the authors want to design a mobile application to learn Javanese characters more easily and more interestingly. In addition to learning more easily, it is also to attract other people to learn Javanese script to preserve Indonesian culture.

\section{RESEARCH RESULTS AND DISCUSSION}

In this study, the modeling uses UML, which is visual modeling as a means of designing and making object-oriented software, so all elements and diagrams are based on the object-oriented paradigm. In general, UML is defined as a language based on graphics or images to visualize, build, and document an object-oriented software development system (Hendrawan, 2018).

Table 1. Actors in the Javanese Script Mobile Application

\begin{tabular}{ll}
\hline No Actor & \multicolumn{1}{c}{ Role } \\
\hline U User can access the application, \\
\\
can read all the info on the \\
letter list menu, there is \\
information about carakan \\
characters, swara, colleagues, \\
murda, and wilangan. In the list \\
of rules menu, the user can read \\
the information about the rules \\
and usage of each character \\
such as wulu, tribe, Taling, \\
pepet, and so on. Then the user \\
can practice questions and \\
evaluate abilities after reading \\
the info and practice questions \\
on the training and evaluation \\
menu.
\end{tabular}


Table 2.Definition of Use Case Diagrams in the Java Script Mobile Application

\begin{tabular}{|c|c|c|}
\hline No & Use Case & Description \\
\hline 1 & Read info & $\begin{array}{l}\text { Users can read info about } \\
\text { Javanese characters on the } \\
\text { letter list menu which } \\
\text { consists of several } \\
\text { characters, and each } \\
\text { character has its } \\
\text { information and rules. In } \\
\text { the rules list menu, there is } \\
\text { also information about the } \\
\text { rules of each character: } \\
\text { wulu, tribe, taling, pepet, } \\
\text { and so on }\end{array}$ \\
\hline 2 & $\begin{array}{l}\text { Listening to } \\
\text { voice and } \\
\text { Record voice }\end{array}$ & $\begin{array}{l}\text { Users can listen to the } \\
\text { correct } \\
\text { pronunciation rules for } \\
\text { each word and letter of } \\
\text { Javanese script. Users can } \\
\text { also record the correct } \\
\text { pronunciation of words } \\
\text { according to the existing } \\
\text { writing, on the training } \\
\text { menu. }\end{array}$ \\
\hline 3 & Write a word & $\begin{array}{l}\text { The user can write down } \\
\text { the answer, namely a word } \\
\text { or letter on the screen in } \\
\text { the training and evaluation } \\
\text { menu. }\end{array}$ \\
\hline 4 & $\begin{array}{l}\text { Work on } \\
\text { practice } \\
\text { questions and } \\
\text { evaluation } \\
\text { questions }\end{array}$ & $\begin{array}{l}\text { Users can work on } \\
\text { problems in practice: read } \\
\text { letters, write letters, read } \\
\text { words, say words. After } \\
\text { that, the user works on } \\
\text { evaluation questions as a } \\
\text { form of testing or } \\
\text { understanding the existing } \\
\text { information. } \\
\text { evaluation is divided into } 3 \\
\text { levels and the higher the } \\
\text { level, the higher the } \\
\text { difficulty level. }\end{array}$ \\
\hline
\end{tabular}

\section{Activity Diagram}

Activity diagrams are used as explanations for program activities regardless of coding or display. Activity diagrams are depicted with symbols, each of which has a meaning and purpose. Activities that need diagrams are the subsystems and don't need to be detailed in them. If everything is made, it will be very long and a lot. Activity diagram of the modeling section of the Unified Modeling Language (UML)(Sukamto \& Shalahuddin, 2018)

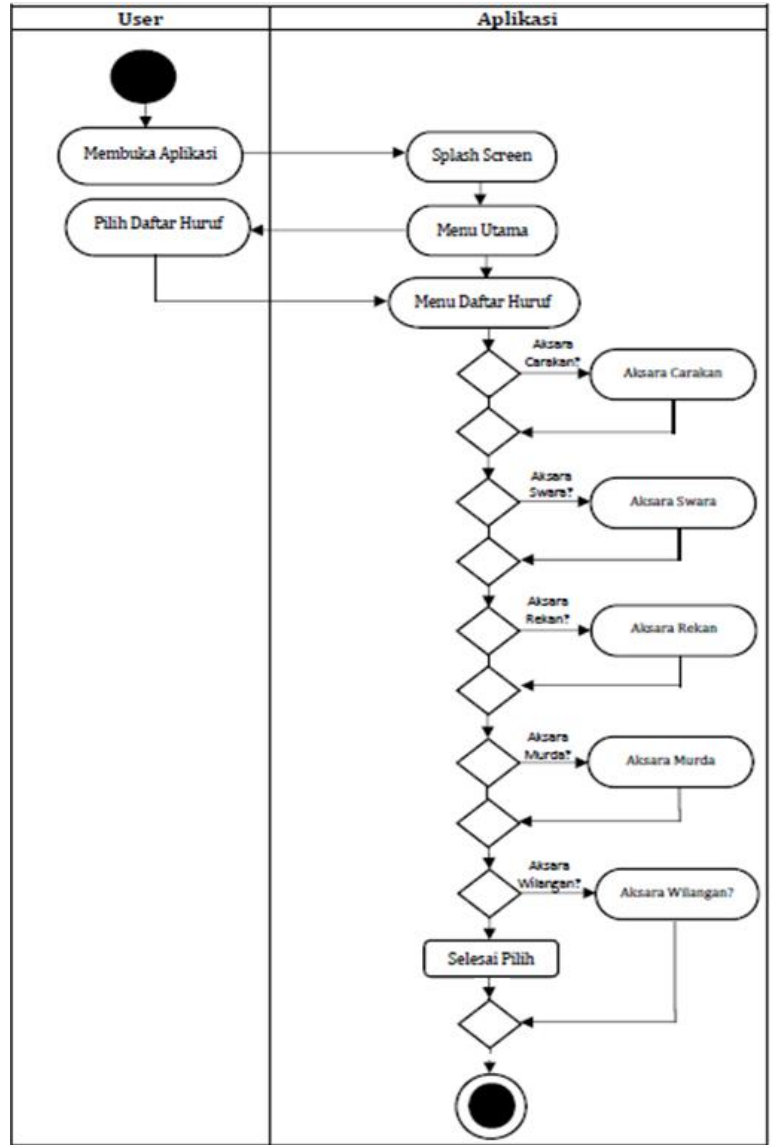

Figure 5. Activity Diagram

\section{Low Fidelity Wireframe Mobile Application} User Interface

The first stage in designing the user interface for the Javanese script learning mobile application is to create a Low Fidelity Wireframe.

\section{a. Login page}

In Figure 6, the low fidelity design of the login menu user interface design consists of: user, password, sign in, forgot password, register.

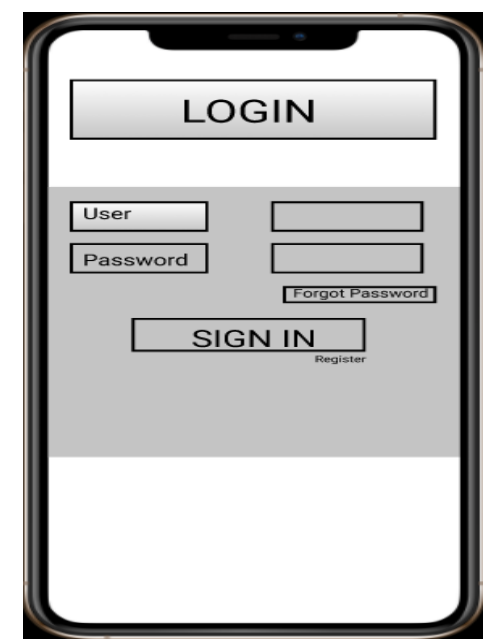

Figure 6. Display Login Menu 


\section{b. Main page}

Figure 7 is the main menu in the Low Fidelity design, applied to a user interface, there are menus: letter list, list of rules, practice, evaluation, turn off the music, about the application, exit.

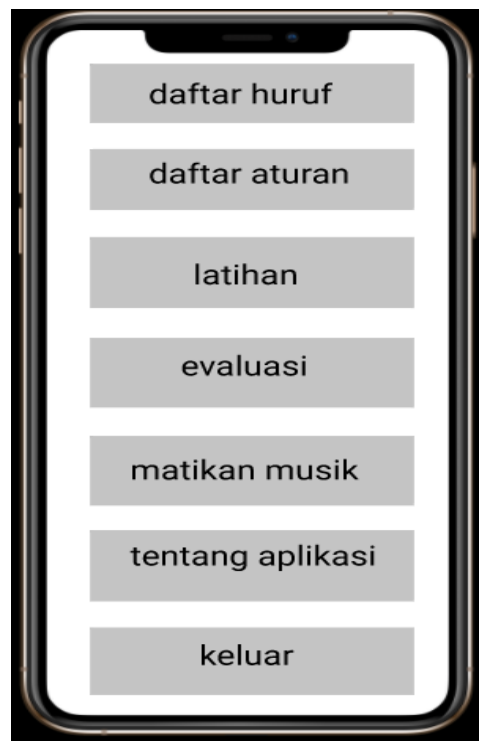

Figure 7. Main Menu Display

c. Character List Menu Page

In Figure 8, the design of the Low Fidelity menu lists letters: carakan characters, swara characters, associates characters, murda characters, wilangan characters.

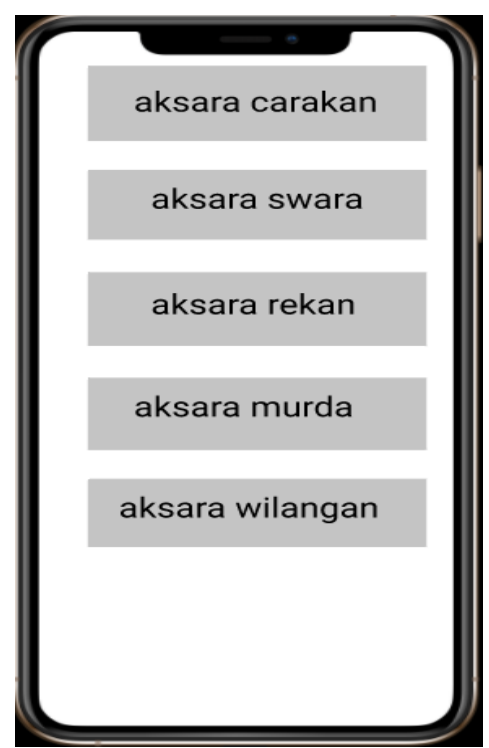

Figure 8. Display Character List

d. Caraka Script Menu page

In Figure 9, in the caraka script there is a menu: see characters, pair rules, and pronunciation rules.

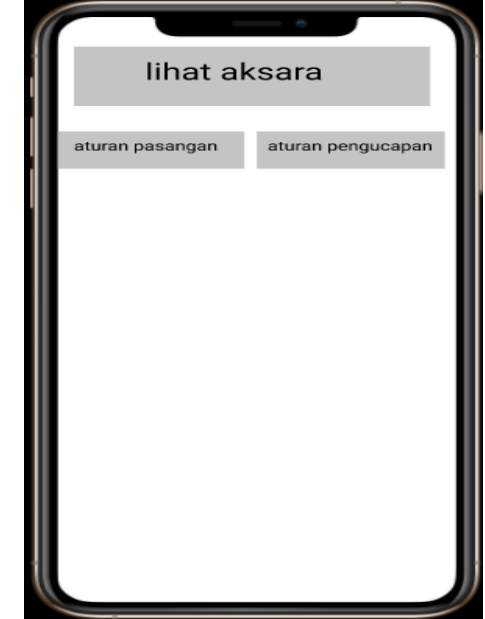

Figure 9. Display of the Caraka Script Menu

\section{High Fidelity Prototype User Interface of Mobile Applications}

The second stage in designing the user interface of the Javanese script learning mobile application is to create a High Fidelity Prototype.

\section{a. Login page}

Page Figure 10, login consists of fields from User Name, Password, and Sign In. To log in, the user can use an active email and a password consisting of a numeric omission. If you forget your password, you can click forgot password, then a link will be sent to reset the password to the registered email address, and if you don't have an account, you can click register and register by filling in data such as name, gender, email address, user name, and password.

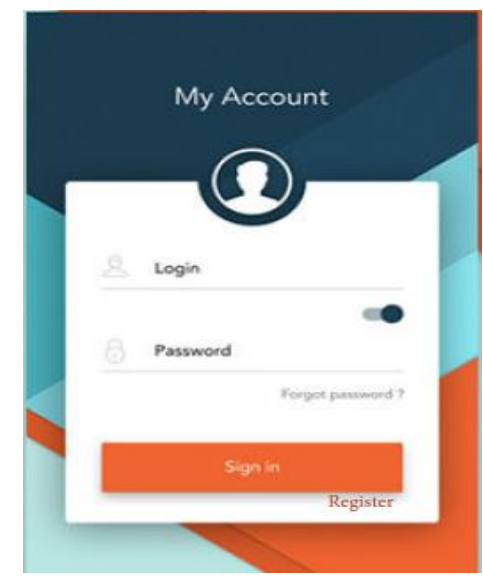

Figure 10. Login page

\section{b. Main Menu Page}

In Figure 11, the design of the High Fidelity main menu page consists of a letter list menu, a list of rules, practice, evaluation, turn off the music, about the application, and exit. Users can interact 
on each menu by clicking the menu and then they will see the information, input data, or click the submenu to see the detailed information.

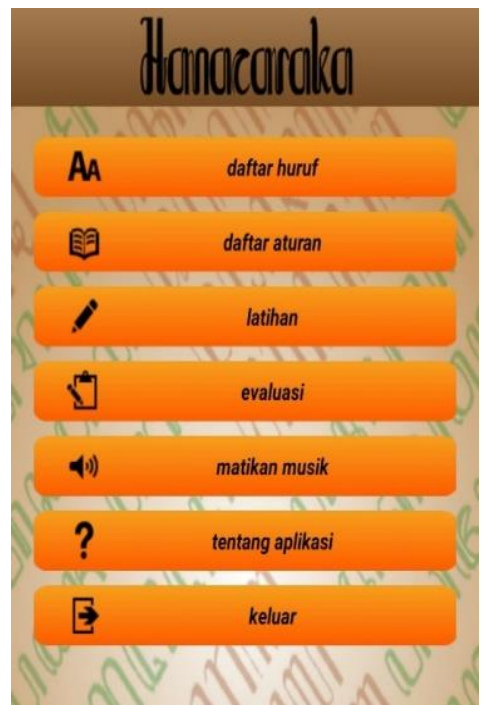

Figure 11. Main Menu Page

\section{c. Character List Menu Page}

In Figure 12, the design of the High Fidelity letter list page displays further information on the following submenus: carakan script, swara script, peer script, murda script, wilangan characters.

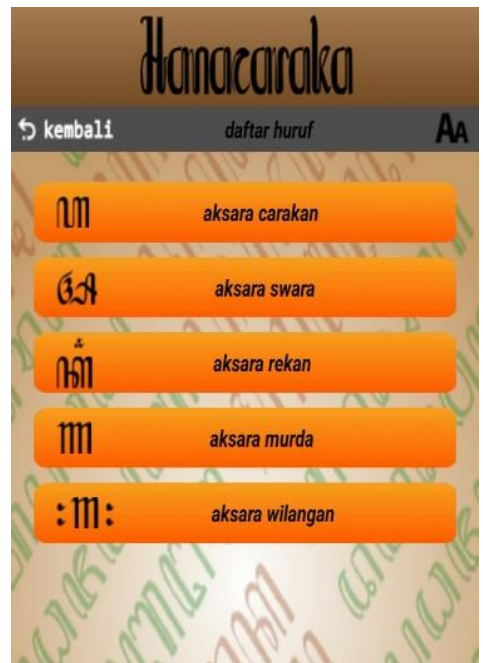

Figure 12. Font Menu page

\section{d. Script Menu page}

In Figure 13, the High Fidelity design of the script menu page contains submenus: see characters, pair rules, and pronunciation rules.

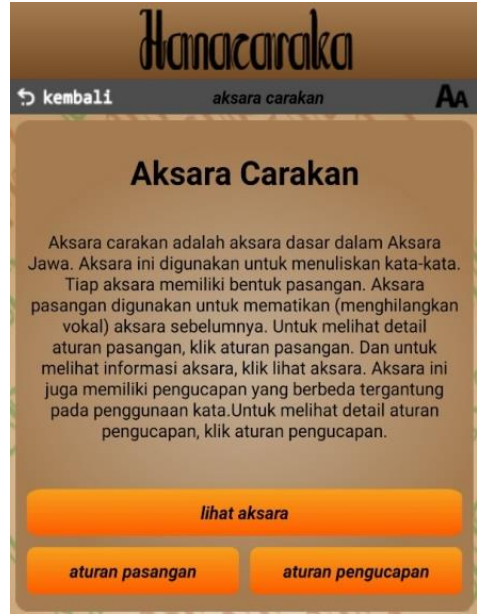

Figure 13. Script Menu page

\section{e. Script Submenu Pages Carakan; See Script}

In Figure 14, the High Fidelity interface design of the script submenu page; view user characters can see info for carakan letters in Latin script and Javanese script.

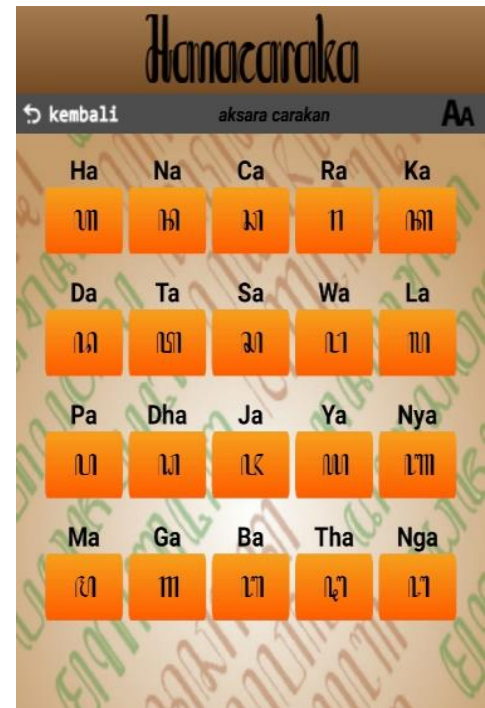

Figure 14. Menu Page See Aksara (Aksara Carakan)

\section{f. Script Submenu Pages Carakan; Pairing Rules}

In Figure 15, the design of the High Fidelity Prototype interface for the submenu script page; This pairing rules the user can see the explanation of the pairing rules in the script along with examples of their use. 


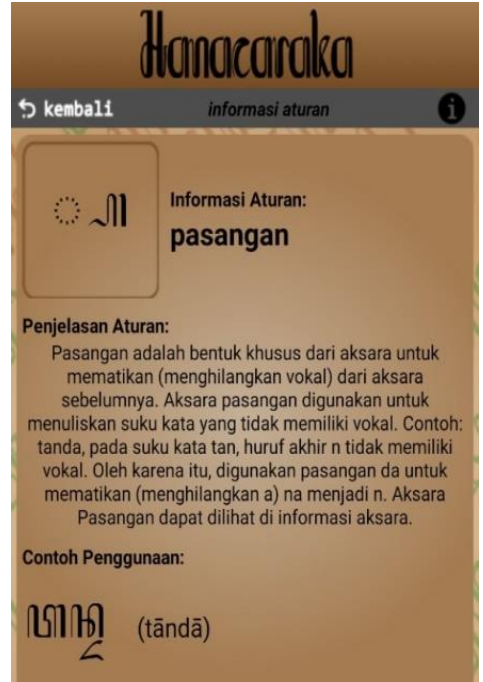

Figure 15. Pair Rules Menu Page (Aksara Carakan)

\section{g. Script Submenu Pages Carakan Pronunciation Rules}

In Figure 16, the High Fidelity Prototype interface design of the submenu script page design; This pronunciation rules users can see the info and listen to examples of the rules for pronouncing carakan characters.

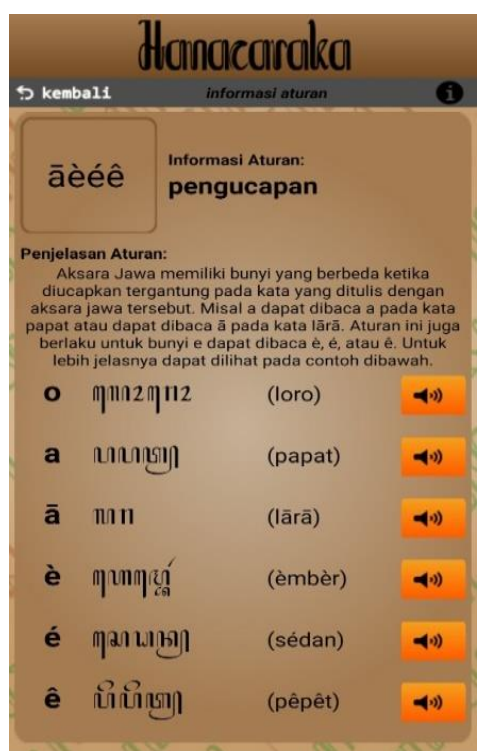

Figure 16. The Pronunciation Rules Menu Page (Characters)

\section{CONCLUSIONS AND SUGGESTIONS}

\section{Conclusion}

By designing a prototype user interface for the Javanese script learning mobile application, we can find out the user's needs for application features and menus, know how users can use and understand features properly, increase user interaction with application systems, and help developers in the development and coding. In this study, there are still many shortcomings, including this application, there is no Javanese script dictionary that can translate Javanese accents into alphabets, and there is also no Javanese scriptwriting menu.

\section{Suggestion}

Further research, the application can be equipped with a dictionary that can translate Javanese characters into alphabets, and also create a menu to write Javanese characters using a touchscreen. So that the Javanese script learning application is more complete and useful for the Javanese script learning process. Then equipped with an animated video related to Javanese script material, so that the application is more interesting for use by elementary school children.

\section{REFERENCES}

Aisa, S., \& Akhriana, A. (2019). Perancangan Aplikasi Pembelajaran Bahasa Inggris Berbasis Android. Jurnal Sistem Informasi Dan Teknologi Informasi, 8(2), 100-110. https://doi.org/10.36499/jinrpl.v1i2.2948

Aribowo, E. K. (2018). Digitalisasi Aksara Jawa dan Pemanfaatannya Sebagai Media Pembelajaran bagi Musyawarah Guru Mata Pelajaran Bahasa Jawa SMP Kabupaten Klaten. Warta LPM, 21(2), 59-70. Retrieved from

http://journals.ums.ac.id/index.php/warta/a rticle/view/5620

Astuti, I. P., Romawati, E. F., \& Widaningrum, I. (2020). Rancang Bangun Aplikasi Mobile Pengenalan Huruf Jawa (Aksara Jawa) Berbasis Android. Jurnal CoSciTech (Computer Science and Information Technology), 1(2), 93-100. Retrieved from http://ejurnal.umri.ac.id/index.php/coscitec h/article/view/2185

Avianto, Y. F., \& Prasida, T. A. S. (2018). Pembelajaran Aksara Jawa Untuk Siswa Sekolah Dasar Dengan Menggunakan Media Board Game. Aksara, 30(1), 133. https://doi.org/10.29255/aksara.v30i1.223. 133-148

Hendrawan, J. (2018). Rancang Bangun Aplikasi Mobile Learning Tuntunan Shalat. INTECOMS: Journal of Information Technology and Computer Science, 1(1), 44-59. https://doi.org/10.31539/intecoms.v1i1.138 Jogiyanto, H. . (2005). Analisa dan Desain Sistem Informasi : Pendekatan Terstruktur Teori dan 
Praktik Aplikasi Bisnis. ANDI, Yogyakarta.

Manuhutu, M., \& Wattimena, J. (2019). Perancangan Sistem Informasi Konsultasi Akademik Berbasis Website. Jurnal Sistem Informasi Bisnis, $9(2), \quad 149$. https://doi.org/10.21456/vol9iss2pp149156

Mesran, M. (2019). Pengantar Logika \& Algoritma. Jakarta: Green Press.

Permana, E. P., \& Nourmavita, D. (2017). Pengembangan Multimedia Interaktif Pada Mata Pelajaran IPA Materi Mendeskripsikan Daur Hidup Hewan Di Lingkungan Sekitar Siswa Kelas IV Sekolah Dasar. Jurnal PGSD: Jurnal Ilmiah Pendidikan Guru Sekolah Dasar, 10(2), 79-85. Retrieved from https://ejournal.unib.ac.id/index.php/pgsd/ article/view/3333/

Pressman, Roger S, P. . (2012). Rekayasa Perangkat Lunak (Pendekatan Praktisi) Edisi 7 - Buku 1 (1st ed.). Yogyakarta: Andi Offset.

Putra, S. D., Eldiana, T. F., \& Aryani, D. (2020). Model Pengembangan Aplikasi Mobile EDakwah Di Masa Pandemi Covid-19 Dengan Metode Prototyping. Journal of Information System, Informatics and Computing, 4(1), 116-121.

Rosadi, D., Widyanto, R. A., \& Sunarni, S. (2018). Rancang Bangun Aplikasi Ayo Belajar Bahasa Arab untuk Anak Usia Dini Berbasis Android. Jurnal Komtika (Komputasi Dan Informatika), 2(1), 29-37. Retrieved from http://journal.ummgl.ac.id/index.php/komti $\mathrm{ka} /$ article/view/2110

RYFA. (2020). Teknik Pengumpulan Data dalam Penelitian Kuantitatif. Retrieved from kumparan.com website: https://kumparan.com/beritaupdate/teknik-pengumpulan-data-dalampenelitian-kuantitatif-1un3C9RXnb1/full

Saputri, K. R. (2016). Analisis Kesalahan Menulis Aksara Jawa Berbasis KTSP Pada Siswa Kelas $V$ SDN Se-Kecamatan Kaliwungu Kabupaten Kudus (Universitas Negeri Semarang). Universitas Negeri Semarang. Retrieved from http://lib.unnes.ac.id/24378/

Suendri, S. (2019). Implementasi Diagram UML (Unified Modelling Language) Pada Perancangan Sistem Informasi Remunerasi Dosen Dengan Database Oracle (Studi Kasus: UIN Sumatera Utara Medan). Algoritma: Jurnal Ilmu Komputer Dan Informatika, 2(2), 1-9. Retrieved from http://jurnal.uinsu.ac.id/index.php/algoritm a/article/view/3148

Sugiyono. (2017). Metode Penelitian Kuantitatif,
Kualitatif, dan R\&D. Bandung: Alfabeta.

Sukamto, R. A., \& Shalahuddin, M. (2018). Rekayasa Perangkat Lunak: Terstruktur dan Berorientasi Objek (Revisi). Bandung: Informatika.

Tilley, S., \& Rosenblatt, H. J. (2017). Systems Analysis and Design (Eleventh). Boston: Cengage Learning.

Wardhani, D., \& Wijaya, A. P. (2020). Perancangan Prototype User Interface Aplikasi Mobile Sistem Informasi Akademik Institut Teknologi Dan Bisnis Bank Rakyat Indonesia. BRI Tech, 1(2), 25-31. Retrieved from https://ejournal.bri-

institute.ac.id/index.php/britech/article/vie $\mathrm{w} / 15$

Wati, R., \& Ernawati, S. (2018). Perancangan Aplikasi Kamus Bahasa Jawa-Indonesia Berbasis Android. Jurnal Techno Nusa Mandiri, 15(2), 93-98. https://doi.org/10.33480/techno.v15i2.17

Widihastuti, I., \& Khosyi, M. (2012). Aplikasi Interaktif Pembelajaran Aksara Jawa. Majalah Ilmiah Sultan Agung, 50(127), 45-52. Retrieved from http://lppmunissula.com/jurnal.unissula.ac.id/index.php /majalahilmiahsultanagung/article/view/64

Widodo, P. P., \& Prabowo, H. (2011). Menggunakan UML. Bandung: Informatika. 